\title{
Announcements
}

\section{The American Association for Thoracic Surgery}

\author{
Eighty-third Annual Meeting \\ May 4-7, 2003 \\ Hynes Convention Center, Boston, Massachusetts
}

\section{Registration}

Both members and nonmembers are urged to preregister as soon as possible using the preregistration form, which can be obtained by visiting the Association Web site at: www.aats.org; writing the Association at: AATS, 13 Elm Street, Manchester, MA 01944; telephone: 978-526-8330, or fax: 978-526-7521. The meeting of the Association is open to all physicians. Guest presenting authors, House Officers, and Fellows will be admitted without payment of a registration fee. House Officers, Fellows, and Residents must provide a letter from their chief of service at the time of registration. Nonmember physicians are required to pay a registration fee of $\$ 250$, and allied health professionals, physician assistants, and perfusionists are required to pay a registration fee of $\$ 150$.

A late fee of $\$ 50.00$ will be applied to all nonmember registrations received after March 31, 2003, and to those registering onsite.

\section{Program* $^{*}$}

\section{Memoranda for Guidance of Speakers and Discussants}

1. In accordance with the By-Laws of the Association, the papers which are read at the meeting shall be given to the Session Moderator immediately after presentation. The paper submitted for consideration for publication in The Journal of Thoracic and Cardiovascular Surgery must be a close relationship in length to the paper presented at the meeting.

2. In publication it is customary to group discussion together on a series of papers. Transcription of the discussion will be forwarded to discussants for review and correction. Any delay in the return of corrected discussions means that publication of all papers on the subject will be held up. Such a delay is manifestly unfair to those who are

*In this program an asterisk after a name means "by invitation."

conscientious in the prompt submission of their remarks for publication. Unreasonable delay will preclude publication.

3. Scientific session presenting authors will be limited to 8 minutes and total discussion will be limited to 12 minutes with each discussant being limited to 2 minutes. Forum speakers will be limited to 5 minutes and total discussion limited to 7 minutes, allowing each discussant no more than 2 minutes.

4. AATS requires PowerPoint slides as the only format accepted for presentations which must be sent according to instructions received by authors. AATS will not be able to accommodate laptop computers at the time of presentation. Presenters will be able to preview their slides in the Speaker Ready Area, Suite 303, of the Hynes Convention Center prior to their presentation.

5. Discussion of Papers. Members, nonmember physicians, and invited speakers have the privilege of discussing papers. All Discussants should register with the Moderator of the Session prior to the opening of the session during which the paper is to be presented. All discussion will be presented from floor microphones and may not be accompanied by slides. Authors will respond to each discussant in sequence.

\section{Of Special Interest to Residents}

1. Cardiothoracic Residents' Luncheon. The Twentysixth Annual Cardiothoracic Residents' Luncheon will be conducted on Tuesday, May 6, 2003 at 12:30 PM at the Hynes Convention Center. Physicians in cardiothoracic residency programs interested in attending this luncheon are advised to preregister by checking the appropriate box on the Annual Meeting preregistration form.

2. The Association would like to extend an invitation to residents to attend one of the three pre-meeting symposia as guests of the Association. Preregistration is required, and Residents should check the appropriate box on the preregistration form to participate in one of the symposia on Congenital Heart Disease, Adult Cardiac Surgery, General Thoracic Surgery, or Developing the Academic Surgeon. 
SATURDAY, MAY 3, 2003

DEVELOPING THE ACADEMIC SURGEON-A SYMPOSIUM

Room 306, Hynes Convention Center

Co-Chairmen: Ralph J. Damiano, Jr

Larry R. Kaiser

1:00 PM KEYNOTE ADDRESS

Do No Harm! Is it Immoral to Utilize Living Persons as Sources of Organs and Tissues for Transplantation?

Arthur Caplan, PhD, Trustee

Professor and Chairman of the Department of Medical Ethics, University of Pennsylvania.

1:20 PM Panel Discussion: Randomized Clinical Trials vs Observational Studies: "Surgical Research or Comic Opera"

Moderator: Larry R. Kaiser, Hospital of the University of Pennsylvania, Philadelphia, Pa.

Panel Members: Joel D. Cooper, Washington University, St Louis, Mo.

Eugene H. Blackstone, Cleveland Clinic Foundation, Cleveland, Ohio.

Eric Rose, Columbia University, Department of Surgery, New York, NY.

2:05 pm The Peer-Review Process in Medical Publishing

An Editor's Perspective: L. Henry Edmunds, Hospital of the University of Pennsylvania, Philadelphia, Pa.

A Reviewer's Perspective: Frank W. Sellke, Beth Israel Deaconess Medical Center, Boston, Mass.

2:50 PM Thinking Financially as Well as Surgically: Implications of Reimbursement on an Academic Surgical Practice

Daniel Cooper, Chief Operating Officer, Department of Surgery, University of Pennsylvania

3:15 PM BREAK

3:35 PM Panel Discussion: Ethical Dilemmas in Cardiothoracic Surgery Role of Private Industry, Patient Confidentiality, Implementation of New Technology, Malpractice Issues

Moderator: Ralph Damiano, Washington University School of Medicine, St Louis, Mo.

Panel Members: Arthur Caplan, University of Pennsylvania, Philadelphia, Pa.

Martin F. McKneally, University of Toronto, Toronto, Ontario, Canada.

Richard D. Weisel, Toronto General Hospital, Toronto, Ontario, Canada

Bruce W. Lytle, Cleveland Clinic Foundation, Cleveland, Ohio.

4:20 PM An Educator's Perspective on Academic Surgery: A Paradigm Shift in Training

Ross Ungerleider, Doernbecher Children's Hospital, Portland, Ore.

4:40 PM Looking at Quality: Assessing One's Own Results in the Context of National or Regional Benchmarks

William C. Nugent, Dartmouth-Hitchcock Medical Center, Lebanon, NH.

5:00 PM

ADJOURN

SATURDAY, MAY 3, 2003

5:00-7:00 PM GENERAL THORACIC BIOLOGY CLUB

Cape Cod/Hyannis Rooms, Marriott Hotel

5:00-7:00 PM ADULT CARDIAC BIOLOGY CLUB

Provincetown/Orleans Rooms, Marriott Hotel 
SUNDAY, MAY 4, 2003

SESSION 1: AATS/STS ADULT CARDIAC SYMPOSIUM

Ballroom, Hynes Convention Center

Chairman: Patrick M. McCarthy, Cleveland Clinic Foundation, Cleveland, Ohio.

8:00 Am What the Surgeon Needs to Know About the Epidemiology and Pathophysiology of Atrial Fibrillation

Robert A. Schweikert, Cleveland Clinic Foundation, Cleveland, Ohio.

8:20 AM Catheter Based Ablation for Atrial Fibrillation

Fred Morady, University of Michigan Medical Center, Ann Arbor, Mich.

8:40 AM Indications, Surgical Techniques, and Late Results of the Classic Maze Procedure (Video) Hartzell V. Schaff, Mayo Clinic, Rochester, Minn.

9:10 Am Minimally Invasive Maze Procedure (Video)

James L. Cox, The World Heart Foundation, Washington, DC.

9:40 AM

Discussion

10:00 AM

BREAK

10:15 АM

New Tools for Atrial Fibrillation Surgery (Video)

Ralph J. Damiano, Jr, Washington University School of Medicine, St Louis, Mo.

10:45 Am New Operative Approaches and Results in Surgery for Atrial Fibrillation (Video)

A. Marc Gillinov, Cleveland Clinic Foundation, Cleveland, Ohio.

$11: 15 \mathrm{AM}$

Panel Discussion

Moderator: Patrick M. McCarthy, Cleveland Clinic Foundation, Cleveland, Ohio.

Case Presentations:

Patient \#1: Tachycardia mediated cardiomyopathy

Patient \#2: Myxomatous mitral regurgitation with dilated left atrium and chronic atrial fibrillation Patient \#3: 82 year old with three-vessel coronary artery disease and atrial fibrillation

12:00 NOON LUNCH

SESSION 2: STATE-OF-THE-ART TREATMENTS OF CORONARY ARTERY DISEASE

12:45 PM Early and Late Results With Coronary Artery Bypass Surgery: The Gold Standard Bruce W. Lytle, Cleveland Clinic Foundation, Cleveland, Ohio.

1:05 PM Drug Eluting Stents: How Much Will Referrals for Coronary Artery Bypass Change?

Martin B. Leon, Lenox Hill Hospital, New York, NY.

1:25 PM New Devices for Proximal and Distal Coronary Anastomoses: Less Morbidity With Smaller Incisions? (Video)

Randall K. Wolf, Ohio State University Medical Center, Columbus, Ohio.

1:45 PM Experimental Approaches to Coronary Revascularization (Video)

Stephen Oesterle, Medtronic, Inc, Minneapolis, Minn.

2:05 PM Panel Discussion

Moderator: Kent W. Jones, Salt Lake City, Utah.

2:30 PM

BREAK

SESSION 3: ISCHEMIC MITRAL REGURGITATION: AN ONGOING SURGICAL CHALLENGE

2:45 PM Ventricular Changes Associated With Ischemic Mitral Regurgitation: Echocardiographic Insights, and Potential Device Solutions

Robert A. Levine, Massachusetts General Hospital, Boston, Mass. 
3:15 PM

3:35 PM

3:55 PM

4:15 PM

5:00 PM

Mitral Valve Repair or Replacement for Ischemic Mitral Regurgitation: Surgical Techniques (Video)

Antonio M. Calafiore, University of Chieti, Chieti, Italy.

Coronary Artery Bypass in a Patient With Moderate Mitral Regurgitation: The Case for Concomitant Mitral Valve Repair (Video)

David H. Adams, Mount Sinai Medical Center, New York, NY.

Coronary Artery Bypass in a Patient With Moderate Mitral Regurgitation: The Case Against Valve Repair

John A. Elefteriades, Yale University School of Medicine, New Haven, Conn.

Panel Discussion

Moderator: D. Craig Miller, Stanford University Medical School, Stanford, Calif.

ADJOURN-WELCOMING RECEPTION

EXHIBIT HALL

SUNDAY, MAY 4, 2003

AATS/STS General Thoracic Symposium

Room 302, Hynes Convention Center

Chairman: Douglas E. Wood, University of Washington Medical Center, Seattle, Wash.

Early Stage Lung Cancer

Moderator: Douglas E. Wood

8:00 AM Current Status of Lung Cancer Screening: Current Challenges and Potential Solutions Phillip M. Boiselle, Beth Israel Deaconess Medical Center, Boston, Mass.

8:15 AM Endoscopic Lung Cancer Detection and Staging

Armin Ernst, Beth Israel Hospital Deaconess Medical Center, Boston, Mass.

8:30 AM $\quad$ PET as a Predictor of Lung Cancer Prognosis

Hubert Vesselle, University of Washington, Seattle, Wash.

8:45 AM How I Do It: Cardiopulmonary function testing and risk assessment

Mark K. Ferguson, University of Chicago, Chicago, Ill.

8:55 AM Controversy: Management of Stage I NSCLC in the High-Risk Patient. Radiation Is Preferred Walter J. Curran, Jr, Thomas Jefferson University, Philadelphia, Pa.

Surgical results are worth the risks

Joe B. Putnam, Jr, Anderson Cancer Center, Houston, Tex.

9:15 АM Discussion

9:45 AM BREAK

Locally Advanced Lung Cancer

Moderator: Valerie W. Rusch

10:15 Aм Development and organization of a multidisciplinary Thoracic Oncology Clinic

Frank C. Detterbeck, University of North Carolina, Chapel Hill, NC.

10:30 AM How I Do It: Carinal Resection

Paolo Macchiarini, PhD, Hannover, Germany. 
10:40 Ам

11:10 AM

11:30 AM

12:00 NOON

1:00 PM

1:15 PM

1:25 PM

1:35 PM

1:50 PM

2:10 PM

2:25 PM

2:35 PM

3:00 PM

3:30 PM
Controversy: Management of Solitary Station N2 Disease

Primary resection

Steven M. Keller, Bronx, NY.

Induction therapy and surgery

Valerie W. Rusch, Memorial Sloan Kettering Cancer Center, New York, NY.

\section{Controversy: Adjuvant Therapy for Resected N1/N2 NSCLC}

\section{Radiation}

Walter J. Curran, Jr, Thomas Jefferson University, Philadelphia, Pa.

\section{Chemotherapy}

Tom J. Lynch, Massachusetts General Hospital, Boston, Mass.

\section{Discussion}

\section{LUNCH}

\section{End-Stage Lung Disease}

Moderator: G. Alexander Patterson

\section{Long-Term Results of LVRS}

Joel D. Cooper, Washington University School of Medicine, St Louis, Mo.

\section{Technical Advances in Lung Reduction}

Tom K. Waddell, University of Toronto, Toronto, Ontario, Canada.

\section{How I Do It: Selection of Patients for Bullectomy}

Henning A. Gaissert, Massachusetts General Hospital, Boston, Mass.

\section{Pulmonary Endarterectomy for Chronic Embolic Pulmonary Hypertension} Michael S. Mulligan, University of Washington, Seattle, Wash.

\section{Controversy: Lung Transplant for Non-infectious Lung Disease}

Single Lung Is Preferred

Walter Klepetko, Vienna, Austria.

Bilateral Lung Is Preferred

Shaf Keshavjee, Toronto General Hospital, Toronto, Ontario, Canada.

Immunologic Advances in Lung Transplantation

James S. Allan, Massachusetts General Hospital, Boston, Mass.

How I Do It: Management of Secondary Pneumothorax

John D. Mitchell, University of Colorado, Denver, Colo.

\section{Discussion}

BREAK

\section{Esophagus}

Moderator: Keith S. Naunheim

Photodynamic therapy and endoscopic mucosal resection for early stage esophageal cancer Kenneth K. Wang, Mayo Clinic, Rochester, Minn. 
Surveillance

Brian J. Reid, University of Washington, Seattle, Wash.

Esophagectomy

Richard I. Whyte, Stanford University, Palo Alto, Calif.

4:15 PM How I Do It: Endoscopic Zenker's Diverticulotomy

Alex G. Little, University of Nevada, Las Vegas, NV.

4:30 PM Discussion

5:00 PM ADJOURN_WELCOMING RECEPTION

EXHIBIT HALL

SUNDAY, MAY 4, 2003

AATS/STS Congenital Heart Symposium

Room 304, Hynes Convention Center

Chairman: Ross M. Ungerleider, Doernbecher Children's Hospital, Portland, Ore.

8:00 AM Introduction and Welcome

Ross M. Ungerleider

SESSION I: IMMEDIATE OUTCOMES FOLLOWING NORWOOD'S PROCEDURE FOR HLHS

8:05 AM Audience response questions to generate reflection of practice patterns by participants

8:15 AM "Conventional" Management

Vaughn A. Starnes, University of Southern California, Los Angeles, Calif.

8:30 AM Alpha Blockade

Glen S. Van Arsdale, University of Toronto, Toronto, Ontario, Canada

8:45 AM Routine Postoperative Ventricular Assist

Irving Shen, Doernbecher Children's Hospital, Portland, Ore.

9:00 AM RV-PA Shunt

Frank L. Hanley, Stanford University, Stanford, Calif.

9:15 Aм Mixed Venous $\mathbf{O}_{2}$ as a Reflection of Outcome Following Variations on the Norwood Procedure Scott M. Bradley, Medical University of South Carolina, Charleston, SC.

9:30 AM

9:45 AM

10:10 AM

10:30 AM

10:50 AM

$11: 10 \mathrm{AM}$

\section{Discussion}

BREAK

\section{SESSION II: COMPLEX RIGHT AND LEFT VENTRICLE OUTFLOW OBSTRUCTION}

\section{Complex LVOT Obstruction}

Thomas L. Spray, Children's Hospital of Philadelphia, Philadelphia, Pa.

Mitral Valve Replacement With Pulmonary Autograft Monocusp and Bovine Jugular Vein Reconstruction of the RVOT

John W. Brown, Indiana University, Indianapolis, Ind.

Non-homograft valved conduits

Kirk R. Kanter, Emory University School of Medicine, Atlanta, Ga.

Stented Bioprostheses

James J. Jaggers, Duke University Medical Center, Durham, NC. 
11:30 Am Surgery for Congenital Heart Disease in the Adult Age: A multicentric European Study Giovanni Stellin, Policlinico Universita, Padova, Italy.

$11: 50 \mathrm{AM}$

12:00 NOON

1:00 PM

$1: 20 \mathrm{PM}$

1:40 PM

2:00 PM

2:20 PM

2:40 PM

3:00 PM

3:20 PM

\section{Discussion}

\section{LUNCH}

SESSION III. DIFFICULT PROBLEMS (to include video as part of presentation when appropriate)

Management of TGA in Infants Who Present at Age More Than 2 Weeks

Pedro J. del Nido, Children's Hospital, Boston, Mass.

Tetralogy of Fallot-Indications for Transatrial Repair

Edward L. Bove, University of Michigan Medical Center, Ann Arbor, Mich.

Repair of Ebstein's Anomaly in Neonates and Young Infants

Christopher J. Knott-Craig, H.S.C./Oklahoma University Medical Center, Oklahoma City, Okla.

TOF with Absent Pulmonary Valve

J. William Gaynor, Children's Hospital of Philadelphia, Philadelphia, Pa.

Tricuspid Atresia with Normally Related Great Vessels

David Ashburn, Toronto, Ontario, Canada

\section{Single Lung Fontan}

Christo I. Tchervenkov, The Montreal Children's Hospital, Montreal, Quebec.

\section{BREAK}

\section{Difficult Problems}

Panel with audience response

This session will convene a panel of "experienced" congenital heart surgeons who will help provide opinions about some of the difficult problems currently being encountered by congenital heart surgeons. The panel will help generate the questions but the floor will be open to the participants for other questions as well. Topics can range from those discussed as a part of the program to others that have not been covered, but will all relate to timely and important issues in the field. It will certainly include the questions about CPB strategies and about Outcome measures. I will ask the panel members to generate questions that can be educational for the audience or which can serve to sample practice patterns of the audience. All questions will be posed as audience response questions and then discussed by the panel.

PANEL:

Moderator: Ross M. Ungerleider, Doernbecker Children's Hospital, Portland, Ore.

Edward L. Bove, University of Michigan Medical Center, Ann Arbor, Mich.

John W. Brown, Indiana University School of Medicine, Indianapolis, Ind.

Constantine Mavroudis, Children's Memorial Hospital, Chicago, Ill.

Pedro J. del Nido, Children's Hospital, Boston, Mass.

Thomas L. Spray, Children's Hospital of Philadelphia, Philadelphia, Pa.

Tom R. Karl, University of California at San Francisco, San Francisco, Calif.

Frank L. Hanley, Stanford University, Stanford, Calif.

Martin J. Elliott, The Great Ormond Street Hospital for Children, London, United Kingdom.

Frank A. Pigula, Children's Hospital of Pittsburgh, Pittsburgh, Pa.

SESSION IV. OUTCOMES AND EDUCATION

4:00 PM

How to Interpret Data-An Overview for Clinical Surgeons

Eugene H. Blackstone, Cleveland Clinic Foundation, Cleveland, Ohio.

4:20 PM

Risk Adjusted Mortality for Congenital Heart Surgery

Kathy Jenkins, Children's Hospital, Boston, Mass. 
4:40 PM The Aristotle Score for Congenital Heart Surgery

Francois Lacour-Gayet, Eppendorf University Hospital, Hamburg, Germany.

5:00 PM

Discussion

$5: 30 \mathrm{PM}$

ADJOURN-WELCOMING RECEPTION

Exhibit Hall

MONDAY, MAY 5, 2003

$7: 45 \mathrm{AM}$

8:00 AM

9:20 AM

$9: 35 \mathrm{AM}$

10:20 AM

$10: 25 \mathrm{AM}$
BUSINESS SESSION (Limited to Members Only)

Ballroom, Hynes Convention Center

SCIENTIFIC SESSION (8 minutes presentation, 12 minutes discussion)

Ballroom, Hynes Convention Center

Moderators: Fred A. Crawford, Jr

Tirone E. David

1. Prospective, Randomized Trial Reveals No Changes in Neurocognitive Function Between Onand Off-Pump Patients

Aftab R. Kherani,* Ronald Lazar,* David D.'Alessandro,* Eric Rose, Barry Esrig, Joanne Festa,* Paul Kurlansky,* Michael Parides,* Lopa Gupta,* Annetine Gelijns,* Faisal Cheema,* Alan Moskowitz,* and Minoo Kavarana,* Mehmet C. Oz, New York, NY, and Miami, Fla.

2. A Decade of Living Lobar Transplantation: Recipient Outcomes

Vaughn A. Starnes, Mark L. Barr,* Marlyn Woo,* Felicia A. Schenkel,* Monica V. Horn,* Michael E. Bowdish,* Renzo Pessotto,* Craig J. Baker,* Ross M. Bremner,* Robbin G. Cohen, Winfield J. Wells, and Richard Barbers,* Los Angeles, Calif.

3. Left-sided Lesions after Anatomic Repair of Transposition of the Great Arteries, Vsd and Coarctation: Surgical Factors.

Alain Serraf,* Siamak Mohamadi,* Emré Belli,* Francois Lacour-Gayet, Bertrand Aupecle,* Regine Roussin, Anita Touchot,* Jacqueline Bruniaux,* and Claude Planché, Le Plessis-Robinson, France.

4. Intramural Hematoma Caused by Penetrating Atherosclerotic Ulcer

Kwang Ree Cho,* Anthony W. Stanson,* D. Dean Potter,* Kenneth J. Cherry, Hartzell V. Schaff, and Thoralf M. Sundt III, Rochester, Minn.

Second Alfred E. Blalock Research Scholar Presentations

Abbas Ardehali, UCLA School of Medicine

Thomas K. Waddell, University of Toronto and Toronto General Hospital

Evarts A. Graham Memorial Traveling Fellowship Presentation

Cliff K. C. Choong, Auckland, New Zealand

INTERMISSION_-VISIT EXHIBITS

Exhibit Hall, 2nd Floor, Hynes Convention Center

Thoracic Surgery Foundation for Research and Education

Ballroom, Hynes Convention Center

John R. Benfield, President

SCIENTIFIC SESSION

Moderators: Joel D. Cooper

Tirone E. David

5. Tricuspid Valve Repair in Hypoplastic Left Heart Syndrome

Richard G. Ohye,* Carlen A. Gomez,* Eric J. Devaney,* and Edward L. Bove, Ann Arbor, Mich. 
6. Results of Lung Volume Reduction Surgery in High Risk Patients Bryan F. Meyers,* Roger D. Yusen,* Stephen S. Lefrak,* Tracey J. Guthrie,* Gail Davis,* G. Alexander Patterson, and Joel D. Cooper, St Louis, Mo.

7. Tight Glycemic Control in Diabetic Patients During Coronary Artery Bypass Graft Surgery Increases Long-Term Survival and Decreases Recurrent Ischemic Events

Harold L. Lazar, Stuart R. Chipkin,* Carmel A. Fitzgerald,* Yusheng Bao,* Howard Cabral,* and Carl A. Apstein,* Boston and Springfield, Mass.

$11: 25 \mathrm{AM}$

PRESIDENTIAL ADDRESS

Thoracic Surgery Education-Responding to a Changing Environment

Fred A. Crawford, Jr, Charleston, South Carolina

Introduced by: Joel D. Cooper

12:15 PM ADJOURN FOR LUNCH-VISIT EXHIBITS

Exhibit Hall, 2nd Floor, Hynes Convention Center

\section{MONDAY AFTERNOON, MAY 5, 2003}

$1: 45 \mathrm{PM}$

SIMULTANEOUS SCIENTIFIC SESSION-ADULT CARDIAC SURGERY (8 minutes presentation, 12 minutes discussion)

Ballroom, Hynes Convention Center

Moderators: Timothy J. Gardner

O. Wayne Isom

8. Propensity Case Match Analysis of Off Pump CABG in Patients With Atheromatous Aortic Disease

Ram Sharony,* Eugene A. Grossi, Paul C. Saunders,* Charles F. Schwartz,* Aubrey C. Galloway, Greg Ribakove,* Alfred T. Culliford, Marc Kanchuger,* Robert M. Applebaum,* Itzhak Kronzon,* and Stephen B. Colvin, New York, NY.

9. Emergency Conversion to Cardiopulmonary Bypass During Attempted Off-Pump Revascularization Results In Increased Morbidity and Mortality

Nirav C. Patel,* Nilesh U. Patel,* John McCabe, V. A. Subramanian, New York, NY.

10. Left Ventricular Reconstruction: Early and Late Results

Lynda L. Mickleborough, Naaem Merchant,* Joan Ivanov,* Vivek Rao,* and Susan Carson,*

Toronto, Ontario, Canada.

11. Optimal Timing of Cardiac Transplantation After Ventricular Assist Device Implantation James S. Gammie,* Leah B. Edwards,* Bartley P. Griffith, Richard N. Pierson IV, and Lana Tsao,* Baltimore, Md; Richmond, Va; and Boston, Mass.

12. LVAD Destination Therapy: An Extended Follow-Up of Outcomes

Soon J. Park, O. H. Frazier, William Piccioni, Sr,* Edward Raines,* William Holman,* Eric Rose, Mehmet Oz, Annetine Gelijns,* Nuala Ronan,* Satoshi Furukawa,* and Walter Dembitsky,

Minneapolis, Minn; Houston, Tex; Chicago, Ill; Lincoln, Neb; Birmingham, Ala; New York, NY;

Philadelphia, Pa; and San Diego, Calif.

3:25 PM

INTERMISSION-VISIT EXHIBITS

Exhibit Hall, 2nd Floor, Hynes Convention Center

4:00 PM

SIMULTANEOUS SCIENTIFIC SESSION-ADULT CARDIAC SURGERY
Ballroom, Hynes Convention Center
Moderators: Timothy J. Gardner
O. Wayne Isom


13. The Long-Term Outcome of Patients With Coronary Disease and Atrial Fibrillation Undergoing the Cox Maze Procedure

Ralph J. Damiano, Jr, Sydney L. Gaynor,* Sunil Prasad,* John P. Boineau,* Richard B. Schuessler,* and James L. Cox, St Louis, Mo.

14. Separated Graft Technique and En Bloc Technique for Arch Vessels Reimplantation During Surgery of the Aortic Arch: A Retrospective Comparative Study

T. Keavi,* Marco Di Eusanio,* Marc Schepens,* Wim Morshuis,* Karl Dossche,* Teruhisa Kazui,* Kazuhiro Ohkura,* Naoki Washiyama,* Roberto Di Bartolomeo,* Davide Pacini,* and Angelo Pierangeli,* Ancona, Italy; Nieuwegein, Netherlands; Hamamtsu, Japan; and Bologna, Italy.

15. Aortic Root Surgery in Marfan's Syndrome: Comparison of Aortic Valve Sparing Reimplantation Versus Composite Grafting Matthias Karck,* Klaus Kallenbach,* Christian Hagl,* Thorsten Walles,* Christine Rhein,* Rainer G. Leyh,* and Axel Haverich, Hannover, Germany.

SIMULTANEOUS SCIENTIFIC SESSION—GENERAL THORACIC SURGERY (8 minutes presentation, 12 minutes discussion)

Room 302, Hynes Convention Center

Moderators: Joel D. Cooper

Larry R. Kaiser

16. Twenty-Year Experience of Lung Transplantation at a Single Center: Influence of Recipient Diagnosis on Long-Term Survival

Marc de Perrot,* Cecilia Chaparro,* Karen McRae,* Thomas K. Waddell,* Denis Hadjiliadis,* Lianne G. Singer,* Andrew F Pierre,* Michael Hutcheon,* and Shaf Keshavjee, Toronto, Ontario, Canada.

17. Prolonged Survival in Patients With Resected Non-Small Cell Lung Cancer and Single Level N2 Disease

Steven M. Keller,* Mark G. Vangel,* Henry Wagner,* Joan H. Schiller,* Arnold M. Herskovic,* Ritsuko Komaki,* Randolph S. Marks,* Michael C. Perry,* Robert B. Livingston,* and David H. Johnson,* Bronx, NY; Boston, Mass; Tampa, Fla; Madison, Wiss; Arlington Heights, Ill; Houston, Tex; Rochester, Minn; Columbia, Mo; Seattle, Wash; and Nashville, Tenn.

18. Results of the American College of Surgeons Oncology Group Trial Z0050: The Utility of PET in Staging Patients With Potentially Operable Non-Small Cell Lung Carcinoma Carolyn E. Reed, David H. Harpole, K. E. Posther,* S. H. Jung,* Robert J. Downey,* Bryan F. Meyers,* Valerie W. Rusch, and Barry A. Siegel,* Charleston, SC; Durham, NC; New York, NY; and St Louis, Mo.

INTERMISSION-VISIT EXHIBITS

Exhibit Hall, 2nd Floor, Hynes Convention Center

SIMULTANEOUS SCIENTIFIC SESSION-GENERAL THORACIC SURGERY

Room 302, Hynes Convention Center

Moderators: Joel D. Cooper

Larry R. Kaiser

19. Lung Cancer Resection Combined With Lung Volume Reduction in Patients With Severe Emphysema

Cliff K. Choong,* Bryan F. Meyers,* Richard J. Battafarano,* Tracey J. Guthrie,* Gail Davis,* G. Alexander Patterson, and Joel D. Cooper, St Louis, Mo. 
20. Respiratory Complications After Pneumonectomy: An Analysis of Incidence, Risk Factors, and Outcome

Nicolas Aubrée,* Jocelyn Grégoire,* Louis F. Jacques,* Michel Piraux,* Liu Guojin,* Yves Lacasse,* and Jean Deslauriers, Ste-Foy, Quebec, Canada.

21. Endotracheal Calcineurin Inhibition Ameliorates Injury in an Experimental Model of Lung Ischemia Reperfusion

Steven M. Woolley,* Alexander S. Farivar,* Robert Thomas,* and Michael S. Mulligan,* Seattle, Wash.

22. Identification of Risk Factors Associated With Atrial Fibrillation After Thoracic Surgery: Prospective Analysis of 2335 Patients

Ara A. Vaporciyan,* Arlene M. Correa,* David C. Rice,* Jack A. Roth, W. Roy Smythe,* Stephen G. Swisher,* Garrett L. Walsh,* and Joe B. Putnam, Jr, Houston, Tex.

23. Efficacy of FDG-PET Imaging in Esophageal Cancer

Seth Force,* Richard J. Battafarano,* Bryan F. Meyers,* Jennifer Bell,* Sara F. Hicks,* Joel D. Cooper, and G. Alexander Patterson, St Louis, Mo.

SIMULTANEOUS SCIENTIFIC SESSION—CONGENITAL HEART DISEASE ( 8 minutes presentation, 12 minutes discussion) Room 304, Hynes Convention Center

Moderators: Thomas L. Spray

Ross M. Ungerleider

24. Incidence Of Atrial Arrhythmias After Long-Term Fontan Circulation

Joachim Weipert,* Christian Noebauer,* Christian Schreiber,* Martin Kostolny,* Bernhard Zrenner,* John Hess,* and Ruediger Lange, Munich, Germany.

25. Brain MRI Demonstrates That Periventricular Leukomalacia Is Common Early After Neonatal Cardiac Surgery

Kristin K. Galli,* Robert A. Zimmerman,* Gail P. Jarvik,* Gil Wernovsky,* Robert R. Clancy,* Lisa M. Montenegro,* William T. Mahle,* Susan C. Nicolson,* Thomas L. Spray, and J. William Gaynor, Philadelphia, Pa; Seattle, Wash; Atlanta, Ga; and Philadelphia, Pa.

26. The Rise and Fall of Plasma Vascular Endothelial Growth Factor Levels During the Single Ventricle Surgical Pathway: One Step Closer to an "Anti-Hepatic Factor?"

Ali Dodge-Khatami,* Narayanswami Sreeram,* Igor I. Tulevski,* Bas A. De Mol,* J. Francois Hitchcock,* and Ger B. Bennink,* Amsterdam and Utrecht, Netherlands.

27. The Influence of Pulmonary Artery Morphology on Results of Surgery for Major Aortopulmonary Collateral Arteries and Complex Congenital Heart Defects Massimo Griselli,* Simon P. McGuirk,* David S. Winlaw,* Oliver Stümper,* Joseph V. De Giovanni,* Paul Miller,* Rami Dhillon,* John G. Wright,* David J. Barron,* and William J. Brawn,* Birmingham, United Kingdom. 
28. Redefining the Impact of Oxygen and Hyperventilation After the Norwood Procedure Scott M. Bradley, Andrew M. Atz,* and Janet M. Simsic,* Charleston, SC.

29. New Approach to the Surgical Management of Multiple Ventricular Septal Defects Christian Olsson,* James L. Wilkinson,* and Christian P. Brizard,* Uppsala, Sweden, and Melbourne, Australia.

30. Cerebral Oxygenation Decreases, and Somatic Oxygenation Increases, Following Cardiopulmonary Bypass With Continuous Cerebral Perfusion for Stage 1 Palliation of Hypoplastic Left Heart Syndrome George M. Hoffman,* Eckehard A. Stuth,* Robert D. Jaquiss, Susan R. Staudt,* Todd J. Troshynski,* Patrick L. Vanderwal,* and James S. Tweddell, Milwaukee, Wis.

31. Favorable Outcome With Heart Transplantation Following Failed Fontan Operation or Cavopulmonary Shunt

Max B. Mitchell,* David N. Campbell, Mark M. Boucek,* Henry M. Sondheimer,* David D. Ivy,* Biagio Pietra,* and Bibhuti Das,* Denver, Colo.

CARDIAC SURGERY FORUM SESSION (5 minutes presentation, 7 minutes discussion) Room 311, Hynes Convention Center Moderators: Irving L. Kron W. Randolph Chitwood

F1. Ethyl Pyruvate Preserves Cardiac Function and Attenuates Infarct Size Following Prolonged Myocardial Ischemia Y. Joseph Woo,* Matthew D. Taylor,* Jeffrey E. Cohen,* Vasant Jayasankar,* Lawrence T. Bish,* Jeffrey Burdick,* Timothy J. Pirolli,* Mark F. Berry,* H. Lee Sweeney,* and Timothy J. Gardner, Philadelphia, Pa.

F2. Immediate Ischemic Preconditioning Based on Somatosensory Evoked Potentials Prevents Spinal Cord Injury Following Descending Thoracic Aorta Crossclamping Ivan Salvador B. Contreras,* Luiz Felipe P. Moreira,* Gerson Ballester,* Bernardo A. De Monaco,* Carmen Lucia P. Lancellotti,* and Sérgio A. Oliveira, São Paulo, Brazil.

F3. Regional Low Flow Perfusion Improves Neurological Outcome Following Deep Hypothermic Circulatory Arrest in Neonatal Piglets

Richard J. Myung,* Matus Petko,* Alexander R. Judkins,* Gregory Schears,* Richard F. Ittenbach,* Robert J. Waibel,* and William M. Decampli,* Philadelphia, Pa.

F4. Cardiac Xenotransplantation: Continuing Progress in the Laboratory Christopher G. A. McGregor,* Sumeet S. Teotia,* Johannes M. Schirmer,* Robert P. Frantz,* Henry D. Tazelaar,* Randall C. Walker,* Guerard W. Byrne,* and John S. Logan,* Rochester, Minn, and Princeton, NJ.

F5. Pretreatment With Phenoxybenzamine Attenuates the Radial Artery's Vasoconstrictor Response to Alpha Adrenergic Stimuli Joel S. Corvera,* Cullen D. Morris,* Jason M. Budde,* Daniel A. Velez,* John D. Puskas,* Omar A. Lattouf, William A. Cooper,* Robert A. Guyton, and Jakob Vinten-Johansen,* Atlanta, Ga.

F6. Higher Bypass Temperature Correlates With Increased White Cell Activation in the Cerebral Microcirculation Vesa Anttila,* Ikuo Hagino,* David Zurakowski,* Hart G. Lidov,* and Richard A. Jonas, Boston, Mass. 
F7. Reduction of Systolic and Diastolic Dysfunction by Retrograde Coronary Sinus Perfusion During Off Pump Coronary Surgery

Manuel Castella* and Gerald D. Buckberg, Los Angeles, Calif.

3:10 PM

$3: 45$ PM

BREAK

\author{
CARDIAC SURGERY FORUM SESSION \\ Room 311, Hynes Convention Center \\ Moderators: Steven F. Bolling \\ Andrew S. Wechsler
}

F8. Pharmacologic Inhibition of Intracellular Caspases Following Ischemia-Reperfusion Attenuates Left Ventricular Remodeling: A Potentially Novel Pathway

William M. Yarbrough,* Rupak Mukherjee,* G. Patricia Escobar,* Jeffrey A. Sample,* Julie E. McLean,* Kathryn B. Dowdy,* Jennifer W. Hendrick,* William C. Gibson,* Amy E. Hardin,* Joseph T. Mingoia,* Patrick C. White,* Ann Stiko,* Robert C. Armstrong,* Fred A. Crawford, Jr, and Francis G. Spinale,* Charleston, SC, and San Diego, Calif.

F9. Pulmonary Arterial Expression of the Hepatocyte Growth Factor Receptor c-Met Switches From Medium to Endothelium After Cavopulmonary Anastomsosis

Akio Ikai,* R. Kirk Riemer,* Xiaoyuan Ma,* Olaf Reinhartz, Frank L. Hanley, and V. Mohan Reddy, Stanford, Calif.

F10. Myocardial Apoptosis Forty-eight Hours After Brain Death: Implications for Donor Heart Dysfunction and Management

Thomas Yeh, Jr,* Mark McDonald,* Mark J. Schroeder,* Stephanie J. Webb,* Steven C. Koenig,* Mary Anne Hauck,* and Constantine Ionan,* Louisville, KY; Columbia, SC; and Fargo, ND.

F11. Pharmacological Platelet Anesthesia by GPIIb/IIIa Antagonist and Argatroban during In Vitro Extracorporeal Circulation

Shinji Kanemitsu* and Isao Yada, Tsu, Japan.

F12. The Influence of pH Strategy on Cerebral and Collateral Circulation During Hypothermic Cardiopulmonary Bypass in Cyanotic Cardiac Patients: Results of a Randomized Trial and Real-Time Monitoring

Takahiko Sakamoto,* Hiromi Kurosawa, Toshiharu Shin'oka,* Mitsuru Aoki,* Masayoshi Nagatsu,* and Yukihisa Isomatsu,* Tokyo, Japan.

F13. Regression Of Postobstructive Vasculopathy After Revascularization Of Chronically Obstructed Pulmonary Artery

Elie Fadel,* Rene Michel,* Saadia Eddahibi,* Renee Bernatchez,* Michel Mazmanian,* Bruno Baudet,* Philippe Dartevelle, and Philippe Herve,* Le Plessis Robinson, France, and Montreal, Canada.

F14. Efforts Toward "Bio-CABG" for Diffuse or "Inoperative" Coronary Artery Disease Koji Ueyama,* Gao Bing,* Makoto Ozeki,* Yasuhiko Tabata,* Kazuhiko Doi,* Kazunobu Nishimura,* Hisayoshi Suma, and Masashi Komeda, Kyoto, Japan.

F15. Inflammatory Response To Cardiac Bypass in Ewe Fetuses: Effects of Steroid Administration or Continuous Hemodiafiltration

Adriano Carotti,* Francesco Emma, ${ }^{*}$ Stefano Picca,* Enrico Iannace, ${ }^{*}$ Sonia B. Albanese,* Mauro Grigioni,* Francesco Meo,* Mario Sciarra,* and Roberto M. Di Donato,* Roma, Italy. 
TUESDAY MORNING, MAY 6, 2003

7:00 AM

L1. Gene Delivery to Aortocoronary Saphenous Vein Grafts in a Large-Animal Model of Intimal Hyperplasia

Jason A. Petrofski,* Jonathan A. Hata,* Thomas R. Gerhig,* Steven I. Hanish,* Matthew L. Williams, * Richard B. Thompson, * Cyrus J. Parsa, * Walter J. Koch, ${ }^{*}$ and Carmelo A. Milano, ${ }^{*}$ Durham, NC.

L2. Preoperative Viral Gene Transfer of Interferon-Beta Prevents Recurrence and Improves Survival in Advanced Thoracic Malignancies

Sunil Singhal,* Robert Kruklitis,* Jacob Greenberg,* Steven M. Albelda,* and Larry R. Kaiser, Philadelphia, Pa.

L3. Blockade of the Mitogen-Activated Protein Kinase/Extracellular Signal Regulated Kinase Pathway by U0126 Attenuates Neuronal Damage Following Circulatory Arrest in Neonatal Piglets: A Novel Therapeutic Approach

Matthew R. Mulloy,* Deog-Gon Cho,* Paul A. Chang,* Mahlon D. Johnson,* Alon S. Aharon, Trevor A. Robison, ${ }^{*}$ Tamara Buckles, ${ }^{*}$ and Davis C. Drinkwater, Jr, Nashville, Tenn, and St Louis, Mo.

L4. C-Reactive Protein Is a Novel Mediator of Endothelial Activation and Vascular Remodeling in Saphenous Veins: A New Target for Restenosis

Subodh Verma,* Shu-Hong Li,* Renke Li,* Paul Fedak,* and Richard D. Weisel, Toronto, Ontario, Canada.

L5. Tumor Necrosis Factor-Alpha From Resident Alveolar Macrophages Is a Key Initiating Factor in Pulmonary Ischemia-Reperfusion Injury

Thomas S. Maxey,* Allan Doctor,* Richard Enelow,* Victor E. Laubach,* and Irving L. Kron, Charlottesville, Va.

L6. Neonatal Vulnerability to Apoptosis-Related Mitochondrial Dysfunction After Cardioplegic Arrest Mohsen Karimi,* Li Xing Wang,* James M. Hammel, Mohamed Abdulhamid,* Elesa W. Barner,* Wei Gen Li,* Thomas D. Scholz,* Jeffrey L. Segar,* and Christopher A. Caldarone, Iowa City, Iowa.

L7. Expression Profiling of Non-Small Cell Lung Carcinoma Identifies Metastatic Genotypes Based on Lymph Node Tumor Burden

Chuong D. Hoang,* Jonathan D’Cunha, * Sherif H. Tawfic,* Robert A. Kratzke,* and Michael A. Maddaus, Minneapolis, Minn.

L8. Late Outcomes in Patients With Uncorrected Mild-Moderate Mitral Regurgitation at the Time of Isolated Coronary Artery Bypass Grafting

Hari R. Mallidi,* Marc P. Pelletier,* Nimesh D. Desai,* Jeri Sever,* George T. Christakis, Gideon Cohen,* Bernard S. Goldman, and Stephen E. Fremes, Toronto, Ontario, Canada.

9:00 AM

50th Anniversary of the First Successful Gibbon Bypass

Denton A. Cooley

Ballroom, Hynes Convention Center

9:05 AM
BASIC SCIENCE LECTURE

Advanced Imaging: Aiding the "Mind's Eye" of the Cardiothoracic Surgeon

Richard White, Head, Section of Cardiovascular Imaging, Cleveland Clinic, Cleveland, Ohio.

Introduced by: Fred A. Crawford, Jr, Charleston, SC. 
9:35 AM SCIENTIFIC SESSION (8 minutes presentation, 12 minutes discussion)

Ballroom, Hynes Convention Center

Moderators: Fred A. Crawford, Jr

Tirone E. David

32. Tricuspid Regurgitation or Dilatation: Which Should Be the Criterion for Surgical Repair?

Gilles D. Dreyfus, Toufan Bahrami,* and K. M. John Chan,* Middlesex, United Kingdom.

33. Risk of Subsequent Primary Neoplasms Developing in Lung Cancer Patients With Prior Malignancies

Malcolm V. Brock,* Anthony Alberg,* Craig Hooker,* Ann Kammera,* Carmen Roig,* and Stephen Yang,* Baltimore, Md.

10:15 AM

11:00 AM

11:05 AM

$11: 45 \mathrm{AM}$

12:15 PM
INTERMISSION_VISIT EXHIBITS

Exhibit Hall

C. WALTON LILLEHEI RESIDENT FORUM AWARD PRESENTATION

Ballroom, Hynes Convention Center

SCIENTIFIC SESSION

Moderators: Fred A. Crawford, Jr

Tirone E. David

34. Determinants of Mortality and Type of Repair in Neonates With Pulmonary Atresia-Intact Ventricular Septum

David A. Ashburn,* Eugene H. Blackstone, Winfield J. Wells, Richard A. Jonas, Frank A. Pigula,*

Peter B. Manning,* Gary K. Lofland,* William G. Williams, Brian W. McCrindle,* and Members,*

Toronto, Ontario, Canada; Cleveland, Ohio; Los Angeles, Calif; Boston, Mass; Pittsburgh, Pa;

Cincinnati, Ohio; Kansas City, Mo; and Toronto, Ontario, Canada.

35. LITA-Radial Artery Composite Grafts as the Technique of Choice for Myocardial

Revascularization in the Elderly: A Prospective Randomized Evaluation

Claudio Muneretto, Alberto Negri,* Gianluigi Bisleri,* Jacopo Manfredi, * Marco Metra,* Savina

Nodari,* and Livio Dei Cas,* Brescia, Italy.

ADDRESS BY HONORED SPEAKER

Frank Culbertson, Captain, USN/Ret, Astronaut

Ballroom, Hynes Convention Center

Introduced by: Fred A. Crawford, Jr, Charleston, SC

ADJOURN FOR LUNCH-VISIT EXHIBITS

Exhibit Hall, 2nd Floor, Hynes Convention Center

CARDIOTHORACIC RESIDENTS' LUNCHEON

Room 200, Hynes Convention Center

TUESDAY AFTERNOON, MAY 6, 2003

$1: 45$ PM

SIMULTANEOUS SCIENTIFIC SESSION_ADULT CARDIAC SURGERY (8 minutes

presentation, 12 minutes discussion)

Ballroom, Hynes Convention Center

Moderators: Bryce W. Lytle

Hartzell V. Schaff

36. Late Incidence and Predictors of Persistent or Recurrent Heart Failure in Patients With Prosthetic Heart Valves

Marc Ruel,* Roy G. Masters,* Fraser D. Rubens,* Andrew L. Pipe,* and Thierry G. Mesana,* Ottawa, Ontario, Canada. 
37. Twenty-Year Experience With The St Jude Medical Mechanical Valve Prosthesis John S. Ikonomidis,* John M. Kratz, Arthur J. Crumbley III,* Martha R. Stroud,* Scott M. Bradley,* Robert M. Sade, and Fred A. Crawford, Jr, Charleston, SC.

38. Mid-Term Results of the Edge-to-Edge Mitral Valve Repair Without Annuloplasty Francesco Maisano,* Alessandro Caldarola,* Andrea Blasio,* Michele De Bonis,* Eustachio Agricola,* Michele Oppizzi,* Giovanni La Canna,* and Ottavio Alfieri,* Milano, Italy.

39. Redo Mitral Surgery via Thoracotomy: Warm Beating Heart Is Superior to Fibrillatory Arrest Matthew A. Romano,* Iva M. Smolens,* Francis D. Pagani,* Richard L. Prager, G. Michael Deeb, and Steven F. Bolling, Ann Arbor, Mich.

40. Hypercholesterolemia Is an Important Risk Factor for Bioprosthetic Heart Valve Calcification, Failure and Reoperation

Robert S. Farivar* and Lawrence H. Cohn, Boston, Mass.

INTERMISSION-VISIT EXHIBITS

Exhibit Hall, 2nd Floor, Hynes Convention Center

SIMULTANEOUS SCIENTIFIC SESSION-ADULT CARDIAC SURGERY

Ballroom, Hynes Convention Center

Moderators: Bryce W. Lytle

Hartzell V. Schaff

41. Is Repair of Aortic Valve Regurgitation a Safe Alternative to Valve Replacement?

Kenji Minakata,* Hartzell V. Schaff, Kenton J. Zehr,* Joseph A. Dearani, Richard C. Daly, Thomas A. Orszulak, Francisco J. Puga, and Gordon K. Danielson, Rochester, Minn.

42. Tricuspid Valve Repair: Durability and Risk Factors for Failure

Sunil K. Bhudia,* Patrick M. McCarthy, Jeevanantham Rajeswaran,* Katherine J. Hoercher,* Bruce W. Lytle, Delos M. Cosgrove, and Eugene H. Blackstone, Cleveland, Ohio.

43. Preoperative Detection and Management With Iloprost of Patients With Immune HeparinInduced Thrombocytopenia Undergoing Open Heart Surgery

George M. Palatianos, Christoforos N. Foroulis,* Maria I. Vassili,* Phaedra Matsouka,* George M. Astras,* George Kantidakis,* Evi Iliopoulou,* and Efthimia Melissari,* Athens, Greece.

5:00 PM

EXECUTIVE SESSION (Members Only)

Ballroom, Hynes Convention Center

TUESDAY AFTERNOON, MAY 6, 2003

SIMULTANEOUS SCIENTIFIC SESSION—GENERAL THORACIC SURGERY (8 minutes presentation, 12 minutes discussion)

Room 302, Hynes Convention Center

Moderators: Carolyn E. Reed

David J. Sugarbaker

44. Pulmonary Metastasectomy for Renal Cell Carcinoma: Determinants of Long-term Survival Sudish C. Murthy,* Kwhanmien Kim,* Thomas W. Rice, Jeevanantham Rajeswaran,* Ronald M. Bukowski,* Malcolm M. Decamp, and Eugene H. Blackstone, Cleveland, Ohio.

45. Long-Term Results After Lung Volume Reduction Surgery in Patients With Alpha-1 Antitrypsin Deficiency

Michaela Tutic,* Konrad Bloch,* Didier Lardinois,* Thomas Brack,* Erich Russi,* and Walter Weder, Zurich, Switzerland. 
46. Preoperative Pulmonary Artery Pressure Impacts Survival After Single Lung Transplantation for COPD

Soon J. Park, Peter S. Dahlberg,* Brian C. Grubbs,* Kay Savik,* Jordan M. Dunitz,* and Marshall I. Hertz,* Minneapolis, Minn.

2:45 PM INTERMISSION-VISIT EXHIBITS

Exhibit Hall, 2nd Floor, Hynes Convention Center

SIMULTANEOUS SCIENTIFIC SESSION-GENERAL THORACIC SURGERY

Room 302, Hynes Convention Center

Moderators: Carolyn E. Reed

David J. Sugarbaker

47. Surgical Benefits of Resection for Metachronous Lung Cancer

Richard J. Battafarano,* Seth Force,* Bryan F. Meyers,* Sara F. Hicks,* Joel D. Cooper, and G. Alexander Patterson, St Louis, Mo.

48. Prevention, Early Detection and Management of Complications Following 328 Consecutive Extrapleural Pneumonectomies

David J. Sugarbaker, William Richards,* Michael Jaklitsch,* Jeanne Lukanich,* Steven Mentzer,*

Yolonda Colson,* Michael Chang,* Philip Linden,* and Raphael Bueno,* Boston, Mass.

49. Combined Bronchoscopy, Mediastinoscopy, and Thoracotomy for Lung Cancer: Who Benefits?

Malcolm M. Decamp, Thomas W. Rice, Sudish C. Murthy,* Kwhanmien Kim,* Daniel P.

Karchmer,* Christopher D. Pierce,* Lisa Rybicki,* and Eugene H. Blackstone, Cleveland, Ohio.

50. Detection of Micrometastases in Mediastinal Lymph Nodes in Non-Small Cell Lung Cancer Patients by EUS-FNA and Real-Time rtPCR

Michael B. Wallace,* Mark I. Block, William E. Gillanders,* Loretta Hoover,* James Ravenel,* Valerie Durkalski,* Brenda J. Hoffman,* Robert H. Hawes,* Gerard A. Silvestri,* Carolyn E. Reed, Mostafa M. Fraig,* David J. Cole,* and Michael Mitas,* Charleston, SC.

51. Optimal Management When Unsuspected N2 Nodal Disease Is Identified During Thoracotomy for Lung Cancer: Cost-Effectiveness Analysis

Mark K. Ferguson, Chicago, Ill.

5:00 PM EXECUTIVE SESSION (Members Only)

Ballroom, Hynes Convention Center

TUESDAY AFTERNOON, MAY 6, 2003

SIMULTANEOUS SCIENTIFIC SESSION—CONGENITAL HEART DISEASE ( 8 minutes presentation, 12 minutes discussion)

Room 304, Hynes Convention Center

Moderators: Richard A. Jonas

Constantine Mavroudis

52. Modified Single Patch Repair of Complete Atrioventricular Canal Defect

Bassem N. Mora,* Gerald R. Marx,* Stephen J. Roth,* Peter Lang,* and Richard A. Jonas, Boston, Mass.

53. Valved Bovine Jugular Vein Conduits for Right Ventricular Outflow Tract Reconstruction: An Attractive and Less Expensive Alternative to Pulmonary Homografts

John W. Brown and Robert K. Darragh,* Indianapolis, Ind.

54. Primary Closure for Postoperative Mediastinitis in Children

Richard G. Ohye,* Robert Maniker,* Eric J. Devaney,* and Edward L. Bove, Ann Arbor, Mich. 
55. Extended Septal Myectomy for Hypertrophic Obstructive Cardiomyopathy With Anomalous Mitral Papillary Muscles or Chordae

Kenji Minakata,* Joseph A. Dearani, Rick A. Nishimura,* Gordon K. Danielson, Rochester, Minn.

3:05 PM

$3: 40$

5:00 PM
INTERMISSION-VISIT EXHIBITS

Exhibit Hall, 2nd Floor, Hynes Convention Center

56. Intermediate Results and Impact of Age on Outcome in Repair of Ebstein's Anomaly Jonathan M. Chen,* Ralph S. Mosca, Karen Altmann,* Beth F. Printz,* Kimara Targoff,* Pamela A. Mazzeo,* and Jan M. Quaegebeur, New York, NY.

57. Age-Related Gene Expression in Children Undergoing Cardiac Surgery for Tetralogy of Fallot Igor E. Konstantinov,* John G. Coles, Cathy Boscarino,* Mark Takahashi,* Jason Goncalves,* Julia Ritter,* and Glen Van Arsdell, Toronto, Ontario, Canada.

58. Blood Group Incompatibility and Accelerated Homograft Fibrocalcifications

Jan T. Christenson,* Dominique Vala,* Jorge Sierra,* Maurice Beghetti,* and Afksendiyos Kalangos,* Geneva, Switzerland.

59. Improved Early Outcome for End-Stage Dilated Paediatric Cardiomyopathy

Anne-Marie McMahon,* Carin Van Doorn,* Michael Burch,* Pauline Whitmore,* Sophia Neligan,* Philip Rees,* Alan Goldman,* Victor Tsang,* Martin Elliott,* and Marc De Leval, London, United Kingdom.

EXECUTIVE SESSION (Members Only)

Ballroom, Hynes Convention Center

\section{TUESDAY AFTERNOON, MAY 5, 2003}

GENERAL THORACIC FORUM SESSION (5 minutes presentation, 7 minutes discussion)

Room 311, Hynes Convention Center

Moderators: Mark S. Allen

Douglas E. Wood

F16. Selective Adenosine-A2A Agonist Improves Cardiac Dysfunction Following Pulmonary Ischemia-Reperfusion Injury

Thomas B. Reece,* Curtis G. Tribble, Thomas S. Maxey,* Jonathan D. Davis,* Andrew M. Schulman,* Victor E. Laubach,* Joel M. Linden,* John A. Kern,* and Irving L. Kron, Charlottesville, Va.

F17. A Clinically Relevant Lung Cancer Prognostic Test From Gene Expression Profiling Data Gavin J. Gordon,* William G. Richards,* David J. Sugarbaker, and Raphael Bueno,* Boston, Mass.

F18. Gene Transfer of Tumor Necrosis Factor Inhibitor Ameliorates Acute Rejection in Lung Allograft

Tsutomu Tagawa,* Benjamin D. Kozower,* Samer A. Kanaan,* Niccolo Daddi,* Jon H. Ritter,* Masashi Muraoka,* Takeshi Nagayasu,* Shinji Akamine,* Tadayuki Oka,* and G. Alexander Patterson, St Louis, Mo, and Nagasaki, Japan.

F19. Combined Histone Deacetylation and Proteosome Inhibition Enhances Apoptosis in Non-Small Cell Lung Cancer

Chadrick E. Denlinger,* R. Michael Broad,* Marty W. Mayo,* and David R. Jones,* Charlottesville, Va. 
F20. Inhibition of Esophageal Cancer by Downregulation of Beta Catenin

N. Veeramachaneni, * H. Kubokura,* G. Alexander Patterson, J. Drebin,* and R. Battafarano, * St Louis, Mo.

F21. Upregulating the Expression of Class I Molecules by Established Murine Tumors Enhances Their Susceptibility to $\mathrm{CD8}^{+}$T Lymphocyte-Mediated Immunotherapy

Robert E. Merritt,* Reiko E. Yamada,* Ronald G. Crystal,* and Robert J. Korst, New York, NY.

F22. Replacement of a Tracheal Defect with a Tissue-Engineered Tracheal Prosthesis: Early Results in Animal Experiments

Jhingook Kim,* Soo Won Suh,* Hojoong Kim,* and Ji Youn Shin,* Seoul, South Korea.

3:10 PM

3:25 PM

BREAK

\author{
GENERAL THORACIC FORUM SESSION \\ Room 311, Hynes Convention Center \\ Moderators: Steven J. Mentzer \\ David H. Harpole, Jr
}

F23. Liposomal Delivery of Heat Shock Protein 72 Into Lung Alveolar Macrophages Downregulates Inflammatory Cytokine Production: Potential Implications for Lung Preservation Daniel R. Meldrum,* Kirstan K. Meldrum,* and John Brown, Indianapolis, Ind.

F24. Transcript Profiling of Patients With N0 Lung Adenocarcinomas To Predict Survival Sunil Singhal,* John Kucharczuk,* Blair Marshall,* Steven M. Albelda,* and Larry R. Kaiser, Philadelphia, Pa.

F25. Effectiveness of a New Bioabsorbable Barrier in Preventing Pleural Adhesions: A Prospective, Randomized, Experimental Study

Domenico Galetta,* Dominique Grunenwald,* Pierre Validire,* and Nicolas Borenstein,* Paris, France.

F26. Altering the Optical Properties of the Bronchial Tree Permits Illumination of an Entire Lung for Photodynamic Therapy

Joseph Friedberg, * Cynthia S. Skema,* Jeffrey Burdick,* Arjun G. Yodh,* Annamarie D. Horan,* Shamus R. Carr,* and Joseph P. Culver,* Philadelphia, Pa; Durham, NC; and Charlestown, Mass.

F27. Simultaneous Progression of Oxidative Stress and Neoangiogenesis in Malignant Transformation of Barrett's Esophagus

Eero I. Sihvo,* Merja I. Auvinen,* Aki Koivistoinen,* Ari L. Harjula, and Jarmo A. Salo,* Helsinki, Finland.

F28. Impact of Retrograde Graft Preservation in Perfadex-Based Pig Lung Transplantation Thorsten Wittwer,* Ulrich F. Franke,* Antonia Fehrenbach,* Tim Sandhaus, ${ }^{*}$ Felix Pfeifer, ${ }^{*}$ Thomas Mueller, * Harald Schubert, ${ }^{*}$ Joachim Richter,* and Thorsten Wahlers, ${ }^{*}$ Jena and Goettingen, Germany.

F29. Inhibition of PI3K/AKT-Dependent Survival Pathways by LY294002 Enhances Taxol Cytotoxicity in Non-Small Cell Lung Cancer and Esophageal Cancer Cells Dao M. Nguyen, * Wilson S. Tsai,* G. A. Chen,* William D. Schrump, * and David S. Schrump, Bethesda, Md.

F30. The Problems of Bleeding and Air Leakage in Pulmonary Redosurgery: Comparison Between Fibrin Sealant and Standard Techniques

P. P. Brega Massone, * C. Lequaglie, * B. Magnani, B. Conti,* and I. Cataldo, * Milan and Pavia, Italy. 
ATTENDEE RECEPTION-A Return to Camelot at the Kennedy Library and Museum John F. Kennedy Library and Museum

(Separate Subscription)

WEDNESDAY MORNING, MAY 7, 2003

EMERGING TECHNOLOGIES AND TECHNIQUES FORUM (7 minutes presentation, 8 minutes discussion)

Ballroom, Hynes Convention Center

Moderators: David H. Adams

Robert W. Emory

T1. Intraoperative Device Closure of Perimembranous Ventricular Septal Defects Without Cardiopulmonary Bypass: Preliminary Results of the Perventricular Approach Zahid Amin,* David A. Danford,* Stacey E. Froemming,* and Jon Lof,* Omaha, Neb.

T2. Innovative Surgical Modifications to Facilitate a Transcatheter Fontan Completion Mark Galantowicz,* John P. Cheatham,* Craig E. Fleishman,* Hamish Munro,* and Samuel Weinstein,* Columbus, Ohio.

T3. Remote Control of Pulmonary Blood Flow: Initial Clinical Experience Antonio F. Corno,* Damien Bonnet,* Nicole Sekarski,* Daniel Sidi,* Pascal Vouhé,* and Ludwig K. Von Segesser, Lausanne, Switzerland, and Paris, France.

T4. Improved Patient Outcomes Using a Temporary Atrial Defibrillator for Postoperative Atrial Fibrillation

Amit N. Patel,* Baron L. Hamman,* Robert F. Hebeler, Jr,* Richard E. Wood,* Brittany Willey,* Amy Patel,* and Harold C. Urschel, Jr, Dallas, Tex.

T5. Successful Performance of the Cox Maze Procedure on the Beating Heart Without Cardiopulmonary Bypass: A Chronic Animal Study Using Bipolar Radiofrequency Ablation Sydney L. Gaynor,* Yosuke Ishii,* Michael D. Diodato,* Sunil M. Prasad,* Kara M. Barnett,* Richard B. Schuessler,* and Ralph J. Damiano, Jr, St Louis, Mo.

T6. Tissue-Engineered Trachea Using Sheep Bone Marrow-Derived From Mesenchymal Stem Cells With TGF- $\boldsymbol{\beta}_{2}$ Released From Biodegradable Microspheres

Koji Kojima,* Ronald A. Ignotz,* Toshihiro Kushibiki,* Yasuhiko Tabata,* Lawrence J. Bonassar,* and Charles A. Vacanti,* Worcester, Mass, and Kyoto, Japan.

T7. Harnessing the Potential of Stem Cells: From Bone Marrow to Highly Functional Semilunar Heart Valve

Fraser W. Sutherland,* Tjorvi E. Perry,* Megan C. Sherwood,* Ying Yu,* Yutaka Masuda,* Dawn L. McLellan,* Cecilia A. Garcia,* George C. Engelmayr, Jr,* Michael S. Sacks,* and John E. Mayer, Jr, Boston, Mass, and Pittsburgh, Pa.

T8. The Impella Recover Microaxial Left Ventricular Assist Device Reduces Mortality for Postcardiotomy Failure: A Three-Center Experience

Michael P. Siegenthaler,* Kerstin Brehm,* Thomas Strecker,* Thorsten Hanke,* Axel Noetzold,* Michael Weyand,* Hans H. Sievers,* and Friedhelm Beyersdorf, Freiburg, Erlangen, and Luebeck, Germany.

T9. Off-Pump Mitral Valve Repair Using the Coapsys Device: A Geometric Evaluation in an Animal Model of Functional Mitral Regurgitation

Masahiro Inoue,* Zoran B. Popovic,* Kazuyoshi Doi,* Soren Schenk,* Yoshio Ootaki,* Hassan Nemeh,* Michael W. Kopcak, Jr,* Raymond Dessoffy,* James D. Thomas,* Patrick M. McCarthy, and Kiyotaka Fukamachi,* Cleveland, Ohio. 
T10. Multicenter Robotic Mitral Valve Repair Trial with the da Vinci System W. Randolph Chitwood, Jr, L. Wiley Nifong,* Michael Argenziano,* Craig Smith, Multi-Center Robotic Mitral Repair Group,* Greenville, NC, and New York, NY.

WEDNESDAY MORNING, MAY 7, 2003

7:00 AM

8:00 AM

$8: 10$ AM

8:20 AM

8:30 AM

8:40 AM

8:50 AM

9:00 AM

9:30 AM
Current Status of Global Initiatives in the Delivery of Cardiothoracic Surgical Care in Developing Countries

Room 302, Hynes Convention Center

Moderator: James L. Cox

Activities of the European Academy of Science and Arts

Felix H. Unger, European Academy of Sciences, Salzburg, Austria.

Current Status and Initiatives in Southeast Asia and French-Speaking Africa

Alain F. Carpentier, Hopital Europeen Georges Pompidou, Paris, France.

Current Status and Initiatives in the Russian Federation

J. Nilas Young, University of California/David, Sacramento, Calif.

Pediatric Cardiac Surgery Initiatives in Shanghai

Richard A. Jonas, Children's Hospital, Boston, Mass.

\section{The Importance of Research at the Local Level in Developing Countries}

Sir Magdi Yacoub, National Health Service, London, United Kingdom.

Coordination of Global Efforts Among Non-Government-Funded Organizations

Thomas Pezzella, President, The World Heart Foundation, Washington, DC.

Panel Discussion

ADJOURN SESSION

WEDNESDAY MORNING, MAY 7, 2003

CONTROVERSIES IN CARDIOTHORACIC SURGERY-PLENARY SESSION

Ballroom, Hynes Convention Center

9:30 AM

Topic: Attending Cardiothoracic Surgeons Should Also Be Subject to Work-Hour Regulations Moderator: D. Craig Miller

Pro: David F. Dinges, PhD

Con: Irving L. Kron

WEDNESDAY MORNING, MAY 7, 2003

CONTROVERSIES IN CARDIOTHORACIC SURGERY—ACQUIRED CARDIAC

CONTROVERSIES

Ballroom, Hynes Convention Center

10:30 Am Topic: Minimal Access Valve Surgery Compromises the Choice of Operation Moderator: Freidrich W. Mohr

Pro: Tirone E. David

Con: W. Randolph Chitwood, Jr

11:15 Am Topic: CABG Should Be Done On-Pump

Moderator: Hartzell V. Schaff

Pro: O. Wayne Isom

Con: Michael J. Mack

12:00 NOON 
WEDNESDAY MORNING, MAY 7, 2003

CONTROVERSIES IN CARDIOTHORACIC SURGERY—GENERAL THORACIC CONTROVERSIES

Room 302, Hynes Convention Center

10:30 AM Topic: Induction Therapy Is Indicated for Esophageal Cancer

Moderator: Steven J. Mentzer

Pro: Richard F. Heitmiller

Con: Thomas W. Rice

11:15 AM Topic: Cancer Screening Is Effective and Cost-Effective

Moderator: Keith S. Naunheim

Pro: David J. Sugarbaker

Con: Mark S. Allen

12:00 NOON ADJOURN

WEDNESDAY MORNING, MAY 7, 2003

CONTROVERSIES IN CARDIOTHORACIC SURGERY—CONGENITAL HEART

CONTROVERSIES

Room 304, Hynes Convention Center

10:30 Aм Topic: Heart and/or Lung Transplantation in Children Should be Abandoned

Moderator: J. William Gaynor

Pro: Constantine Mavroudis

Con: Charles B. Huddleston

11:15 Am Topic: First Stage Norwood Procedure Is Enhanced by Right Ventricular to Pulmonary Artery Conduit

Moderator: Ross M. Ungerleider

Pro: Shunji Sano

Con: Edward I. Bove

12:00 NOON ADJOURN

\section{The American Association for Thoracic Surgery Graham Traveling Fellowship, 2004-2005}

\section{STIPEND $\$ 75,000$}

$\mathrm{T}$

The American Association for Thoracic Surgery Evarts A. Graham Memorial Traveling Fellowship was established in 1951 by The American Association for Thoracic Surgery. Administered through the Graham Educational Research Foundation Fellowship grants support study by young cardiothoracic surgeons from outside North America at sites of their choice within North America and include travel between sites. Goals of the program are to broaden overall training and increase international contacts. Each Fellow should plan to have one primary center for his/her activities where he/she should spend from six to nine months. The Fellow should have identified an individual at that center who will act as his/her sponsor and assist in planning the course of study at the host institution and at other institutions. In addition to the primary center, the Fellow is encouraged to plan to spend shorter periods of time at other secondary centers to enhance the Fellowship experience.
Awards are made to surgeons of unique promise who have been regarded as having the potential for later international thoracic surgical leadership. Since the inception of the Graham Fellowship, 50 young surgeons from 27 countries have completed the Fellowship.

The Fellowship provides a stipend of $\$ 75,000$, a major portion of which is intended for traveling expenses incurred when visiting other medical centers. The Fellowship also provides two round-trip coach air fares from the recipient's country to his/her primary center. The dates of the beginning and ending of the Fellowship year should be scheduled to coincide with the Annual Meeting of The American Association for Thoracic Surgery in Toronto in April 2004. The Fellow will be introduced at this meeting and his/her predecessor will give a report of his/her year's experience to the Plenary Session. The Fellow will be expected to present a summary of his/her year's experience at the 2004 Annual Meeting, 
which will take place at the Moscone onvention Center, San Francisco, California, April 2-6, 2005.

The Fellow should become involved predominantly with observation, consultation, teaching, and research at a variety of thoracic surgical training centers during the twelve months. Patient contact will be determined by the sponsoring surgeon and will conform to the regulations and licensing requirements of the state, province, or country in which he/she is studying. A candidate should have completed his/her formal training in general surgery and in thoracic and cardiovascular surgery, but he/she should not have reached a senior position. Candidates must be sufficiently proficient in English to realize the full benefits of the Fellowship. Candidates should not have received significant training in North America prior to making application for this award.

Applications for the Fellowship are available from:
Irving L. Kron, MD, President

Graham Education and Research Foundation

Thirteen Elm Street

Manchester, MA 01944-1314

USA

Telephone 978-526-8330; fax 978-526-4018

For additional information and to download an application, please visit the AATS Web site at: www.aats.org/academic/ fellowships.

Completed applications must be returned no later than July 1, 2003. The selected candidate will be notified by December 15, 2003.

\section{Evarts A. Graham Memorial Traveling Fellows}

\begin{tabular}{|c|c|c|}
\hline lst & $1951-52$ & L. L. Whytehead, MD, FRCS \\
\hline 2nd & $1953-54$ & $\begin{array}{l}\text { Winnipeg, Manitoba, Canada } \\
\text { W. B. Ferguson, MB, FRCS }\end{array}$ \\
\hline & & Newcastle-upon-Tyne, England \\
\hline 3 rd & $1954-55$ & $\begin{array}{l}\text { Lance L. Bromley, MChir, FRCS } \\
\text { London, England }\end{array}$ \\
\hline 4th & $1955-56$ & $\begin{array}{l}\text { Raymond L. Hurt, FRCS } \\
\text { Radlett Herts, England }\end{array}$ \\
\hline 5 th & $1956-57$ & $\begin{array}{l}\text { Mathias Paneth, FRCS } \\
\text { London, England }\end{array}$ \\
\hline 6th & $1957-58$ & $\begin{array}{l}\text { Peter L. Brunnen, FRCS } \\
\text { Aberdeen, Scotland }\end{array}$ \\
\hline 7 th & $1958-59$ & $\begin{array}{l}\text { N G. Meyne, MD } \\
\text { Amsterdam, The Netherlands }\end{array}$ \\
\hline 8th & $1960-61$ & $\begin{array}{l}\text { Godrej S. Karai, MD } \\
\text { Calcutta, India }\end{array}$ \\
\hline 9th & $1961-62$ & $\begin{array}{l}\text { Fritz Helmer, MD } \\
\text { Vienna, Austria }\end{array}$ \\
\hline 10th & $1962-63$ & $\begin{array}{l}\text { Theodor M. Scheinin, MD } \\
\text { Oulu, Finland }\end{array}$ \\
\hline 1lth & $1963-64$ & $\begin{array}{l}\text { Masahiro Saigusa, MD } \\
\text { Tokyo, Japan }\end{array}$ \\
\hline 12 th & $1963-64$ & $\begin{array}{l}\text { Adar J. Hallen, MD } \\
\text { Uppsala, Sweden }\end{array}$ \\
\hline 13th & $1964-65$ & $\begin{array}{l}\text { Stuart C. Lennox, MD } \\
\text { London, England }\end{array}$ \\
\hline 14 th & $1964-65$ & $\begin{array}{l}\text { Elias Carapistolis, MD, FACS } \\
\text { Thessaloniki, Greece }\end{array}$ \\
\hline 15 th & $1965-66$ & $\begin{array}{l}\text { Gerhard Friehs, MD } \\
\text { Graz, Austria }\end{array}$ \\
\hline 16th & $1965-66$ & $\begin{array}{l}\text { Ary Blesovsky, MD } \\
\text { London, England }\end{array}$ \\
\hline 17 th & $1966-67$ & $\begin{array}{l}\text { C. Peter Clarke, FRACS } \\
\text { Fitzroy, Australia }\end{array}$ \\
\hline 18 th & $1966-67$ & $\begin{array}{l}\text { G. B. Parulkar, MD } \\
\text { Bombay, India }\end{array}$ \\
\hline
\end{tabular}

\begin{tabular}{|c|c|c|}
\hline 19th & $1967-68$ & $\begin{array}{l}\text { Claus Jessen, MD } \\
\text { Copenhagen, Denmark }\end{array}$ \\
\hline 20th & $1969-70$ & Peter Bruecke, MD \\
\hline & & Linz-Puchenau, Austria \\
\hline $21 \mathrm{st}$ & $1970-71$ & $\begin{array}{l}\text { Michel S. Slim, MD } \\
\text { Beirut. Lebanon }\end{array}$ \\
\hline 22nd & $1971-72$ & $\begin{array}{l}\text { Severi Pellervo Mattila, MD } \\
\text { Helsinki, Finland }\end{array}$ \\
\hline 23rd & $1972-73$ & $\begin{array}{l}\text { Yasuyuki Fujiwara, MD } \\
\text { Tokyo, Japan }\end{array}$ \\
\hline 24th & $1973-74$ & $\begin{array}{l}\text { Marc Roger de Leval, MD } \\
\text { London, England }\end{array}$ \\
\hline 25 th & $1974-75$ & $\begin{array}{l}\text { J. J. DeWet Lubbe, MD } \\
\text { Bellville, Republic of South Africa }\end{array}$ \\
\hline 26th & $1975-76$ & $\begin{array}{l}\text { Mieczyslaw Trenkner, MD } \\
\text { Gdansk, Poland }\end{array}$ \\
\hline 27 th & $1976-77$ & $\begin{array}{l}\text { Bum Koo Cho, MD } \\
\text { Seoul, Korea }\end{array}$ \\
\hline 28th & $1977-78$ & $\begin{array}{l}\text { Alan William Gale, MD, FRACP, FRACS } \\
\text { Sydney, Australia }\end{array}$ \\
\hline 29th & $1978-79$ & $\begin{array}{l}\text { Eduardo Otero Coto, MD } \\
\text { Valencia, Spain }\end{array}$ \\
\hline 30 th & $1980-81$ & $\begin{array}{l}\text { Richard Firmin, MD } \\
\text { London, England }\end{array}$ \\
\hline $31 \mathrm{st}$ & $1981-82$ & $\begin{array}{l}\text { Claudio A. Salles, MD } \\
\text { Belo Horizonte, Brazil }\end{array}$ \\
\hline $32 \mathrm{nd}$ & $1982-83$ & $\begin{array}{l}\text { Yasuhisa Shimazaki, MD } \\
\text { Osaka, Japan }\end{array}$ \\
\hline $33 r d$ & $1983-84$ & $\begin{array}{l}\text { Georg S. Kobinia, MD } \\
\text { Linz, Austria }\end{array}$ \\
\hline 34 th & $1984-85$ & $\begin{array}{l}\text { Aram Smolinsky, MD } \\
\text { Tel Hashomer, Israel }\end{array}$ \\
\hline 35 th & $1985-86$ & $\begin{array}{l}\text { Florentino J. Vargas, MD } \\
\text { Buenos Aires, Argentina }\end{array}$ \\
\hline 36th & $1986-87$ & $\begin{array}{l}\text { Ari L. J. Harjula, MD } \\
\text { Helsinki, Finland }\end{array}$ \\
\hline
\end{tabular}




\begin{tabular}{|c|c|c|}
\hline 37 th & $1987-88$ & $\begin{array}{l}\text { Byung-Chul Chang, MD } \\
\text { Seoul, Korea }\end{array}$ \\
\hline \multirow[t]{2}{*}{ 38th } & $1988-89$ & Wang Cheng, MD \\
\hline & & Wuhan, The People's Republic of China \\
\hline \multirow[t]{2}{*}{ 39th } & $1989-90$ & Christopher J. Knott-Craig, MD \\
\hline & & Cape Town, Republic of South Africa \\
\hline \multirow[t]{2}{*}{ 40th } & $1991-92$ & Ko Bando, MD \\
\hline & & Okayama, Japan \\
\hline \multirow[t]{2}{*}{$41 \mathrm{st}$} & $1992-93$ & Timothy E. Oaks, MD \\
\hline & & Hershey, Pennsylvania, USA \\
\hline 42nd & 1993-94 & $\begin{array}{l}\text { Alain E. Serraf, MD } \\
\text { Creteil, France }\end{array}$ \\
\hline 43rd & $1995-96$ & Cornelius McKown Dyke, MD \\
\hline & & Richmond, Va, USA \\
\hline 44th & 1996-97 & $\begin{array}{l}\text { Monica Robotin-Johnson, MD } \\
\text { Sydney, Australia }\end{array}$ \\
\hline
\end{tabular}

\begin{tabular}{|c|c|c|}
\hline 45th & $1997-98$ & Jun Wang, MD \\
\hline 46th & 1998-99 & Christian Kreutzer, MD \\
\hline 47th & $1999-2000$ & $\begin{array}{l}\text { Anders Franco-Cereceda, MD } \\
\text { Stockholm, Sweden }\end{array}$ \\
\hline 48th & $2000-01$ & $\begin{array}{l}\text { Albertus Scheule, MD } \\
\text { Tuebingen, Germany }\end{array}$ \\
\hline 49th & 2001-02 & $\begin{array}{l}\text { Anna Maria Ciccone, MD } \\
\text { Rome, Italy }\end{array}$ \\
\hline 50th & $2002-03$ & $\begin{array}{l}\text { Cliff K. C. Choong, MD } \\
\text { Auckland, New Zealand }\end{array}$ \\
\hline $51 \mathrm{st}$ & 2003-04 & $\begin{array}{l}\text { Edvin Prifti, MD } \\
\text { Tirana, Albania }\end{array}$ \\
\hline
\end{tabular}

\section{The American Association for Thoracic Surgery Second John Alexander Research Scholarship, 2004-2006}

\section{STIPEND \$50,000 PER YEAR}

$\mathrm{T}$ he American Association for Thoracic Surgery announces the AATS Second John Alexander Research Scholarship to provide an opportunity for research, training, and experience for a North American surgeon committed to pursuing an academic career in cardiothoracic surgery. The scholarship will be funded by the Association and administered by the Graham Education and Research Foundation.

The research program must be undertaken within the first three years after completion of an approved cardiothoracic residency. Applications for the scholarship may be submitted during the candidate's final year of cardiothoracic residency or during his or her first two years in an academic position. The duration of the scholarship is to be two years.

The yearly stipend shall be $\$ 50,000$ paid to the host institution. In addition, a grant of $\$ 5,000$ per year shall be made for support of research supplies, travel, and other legitimate academic expenses of the scholar. Applications for the scholarship are available from the Secretary of The American Association for Thoracic Surgery. The application will consist of three components:

1. The candidate must submit a proposal for the research to be undertaken and a statement of career plans and how the research activity will relate to the candidate's academic career.

2. The Director of the laboratory in the institution at which the research will be performed shall submit an endorsement of the proposal and indicate the facilities and degree of support available for the candidate's research.
3. The Chair of the candidate's department shall submit his or her endorsement of the proposal and indicate the willingness of the institution to provide an academic appointment for the candidate upon completion of the scholarship.

The application and its three components shall be submitted to the Secretary of The American Association for Thoracic Surgery by July 1, 2003. Announcement of the award will be made by the President of The American Association for Thoracic Surgery by December 15, 2003. The Scholarship will begin July 1, 2004. Following completion of the two-year program the scholar shall submit a written report of his/her research activities to the membership of the Association. In May 2007 the Scholar shall present a five-minute report of his/her experience at the Plenary Session of the AATS annual meeting.

Applications for the scholarship are available from:

Irving L. Kron, MD, Secretary

The American Association for Thoracic Surgery

Thirteen Elm Street

Manchester, MA 01944-1314

978-526-8330: fax 978-526-4018

Applications may be downloaded from the AATS Web site at: http://www.aats.org/research/grants. 


\section{The American Association for Thoracic Surgery Research Scholars}

Edward D. Churchill, Research Scholar

Alfred Blalock Research Scholar

John H. Gibbon, Jr. Research Scholar

Alton Ochsner Research Scholar

Robert E. Gross Research Scholars

John Alexander Research Scholar

Andrew G. Morrow Research Scholar

Dwight Harken Research Scholar

Second Edward D. Churchill Research Scholar

Second Alfred Blalock Research Scholars

Second John H. Gibbon, Jr. Research Scholars

Second Alton Ochsner Research Scholars

Second Robert E. Gross Research Scholars
1986-1988

1988-1990

1990-1992

1992-1994

1994-1996

1996-1998

1997-1999

1998-2000

1999-2001

2000-2002

2001-2003

2002-2004

2003-2005
Mark K. Ferguson, MD

University of Chicago

Gus J. Vlahakes, MD

Massachusetts General Hospital

Donald D. Glower, MD

Duke University Medical Center

David H. Adams, MD

Brigham and Women's Hospital

Mehmet C. Oz, MD

Columbia-Presbyterian Medical Center

Thoralf Mauritz Sundt III, MD

Washington University School of Medicine

Richard Norris Pierson III, MD

Vanderbilt University Medical Center

Stephen C. Yang, MD

Johns Hopkins University School of Medicine

Bruce Rosengard, MD

University of Pennsylvania

Joseph B. Shrager, MD

University of Pennsylvania School of Medicine

Abbas Ardehali, MD

UCLA School of Medicine

Thomas K. Waddell, MD

University of Toronto/Toronto General Hospital

Richard J. Battafarano, MD

Washington University School of Medicine

Carmelo A. Milano, MD

Duke University Medical Center

Yolonda L. Colson, MD

Brigham \& Women's Hospital

Michael S. Mulligan, MD

University of Washington

Ross H. Bremner, MD

University of Southern California

Keck School of Medicine

Vivek Rao, MD

Toronto General Hospital 


\section{The American Association for Thoracic Surgery}

\section{Announcement of 2003 Annual Meeting}

$\mathrm{T}$ he Eighty-third Annual Meeting of The American Association for Thoracic Surgery will be held May 4-7, 2003, in Boston, Massachusetts, at the Hynes Convention Center. The meeting of the Association is open to all physicians. House Officers and Fellows will be admitted without payment of a registration fee upon presentation of a letter from their Chief of Service either during pre-registration or at the time of registration. Nonmember physicians will be required to pay a $\$ 250$ registration fee. Members, nonmember physicians, and invited speakers will have the privilege of discussing papers.

\section{Requests for Preregistration Forms and Hotel Reservations}

Information on the 2003 Annual Meeting, including registration, hotel accommodations, and the social program, is available on our Web site at www.aats.org.

\section{The Western Thoracic Surgical Association}

\section{Announcement of 2003 Annual Meeting}

$\mathrm{T}$ he Twenty-ninth Annual Meeting of The Western Thoracic Surgical Association will be held June 18-23, 2003, at La Costa Resort in Carlsbad, California. The scientific sessions are open to all duly qualified physicians. Participation in other Association activities for members, invited guests, and program participants will require payment of a social registration fee.

\section{Requests for Meeting Information}

Meeting preregistration and hotel registration forms are available from:

The Western Thoracic Surgical Association

Thirteen Elm Street

Manchester, Massachusetts 01944-1314

978-526-8330; fax: 978-526-7521

e-mail: wtsa@prri.com

www.westernthoracic.org

\section{Application for Membership}

Applications for membership in the Association must have been received by the Membership Committee Chair no later than March
1, 2003, to be considered at the following annual meeting. Applicants must be sponsored by three members of the Association who are not members of the Membership Committee. Application forms will be issued only to sponsoring members.

Address correspondence to:

Chair, Membership Committee

The Western Thoracic Surgical Association

Thirteen Elm Street

Manchester, Massachusetts 01944

978-526-8330; fax: 978-526-4018

\section{The American Board of Thoracic Surgery}

\section{Notices}

7 he part I (written) examination will be held at the Radisson Hotel O'Hare, Rosemont, Chicago, Illinois, on November 23, 2003. The closing date for registration is August 1, 2003. Those wishing to be considered for examination must request an application since it is not automatically sent.

To be admissible for the Part II (oral) examination, a candidate must have successfully completed the Part I (written) examination.

A candidate applying for admission to the certifying examination must fulfill all the requirements of the Board in force at the time the application is received. Please address all communications to the American Board of Thoracic Surgery, One Rotary Center, Suite 803, Evanston, IL 60201 (telephone: 847-475-1520).

\section{Requirements for Recertification/Maintenance of Certification in 2003}

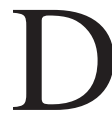
iplomates of the American Board of Thoracic Surgery who plan to participate in the Recertification/Maintenance of Certification process in 2003 must hold an active medical license and must hold clinical privileges in thoracic surgery. In addition, a valid certificate is an absolute requirement for entrance into the recertification/maintenance of certification process. If your certificate has expired, the only pathway for renewal of a certificate is to take and pass the Part I (written) and the Part II (oral) certifying examinations.

The American Board of Thoracic Surgery will no longer publish the names of individuals who have not recertified in the American Board of Medical Specialties directories. The Diplomate's name will be published upon successful completion of the recertification/maintenance of certification process.

The CME requirements include 70 Category I credits in either cardiothoracic surgery or general surgery earned during the 2 years prior to application. SESATS and SESAPS are the only selfinstructional materials allowed for credit. Category II credits are 
not allowed. The Physicians Recognition Award for recertifying in general surgery is not allowed in fulfillment of the CME requirements. Interested individuals should refer to the 2003 Booklet of Information for a complete description of acceptable CME credits.

Diplomates should maintain a documented list of their major cases performed during the year prior to application for recertification. This practice review should consist of 1 year's consecutive major operative experiences. If more than 100 cases occur in 1 year, only 100 should be listed.

Candidates for recertification/maintenance of certification will be required to complete all sections of the SESATS self-assessment examination. It is not necessary for candidates to purchase SESATS individually because it will be sent to candidates after their application has been approved.

Diplomates may recertify the year their certificate expires, or if they wish to do so, they may recertify up to 2 years before it expires. However, the new certificate will be dated 10 years from the date of expiration of their original certificate or most recent recertification certificate. In other words, recertifying early does not alter the 10-year validation.

Recertification/maintenance of certification is also open to Diplomates with an unlimited certificate and will in no way affect the validity of their original certificate.

The deadline for submission of applications for the recertification/maintenance of certification process is May 10 each year. A brochure outlining the rules and requirements for recertification/maintenance of certification in thoracic surgery is available upon request from the American Board of Thoracic Surgery, One Rotary Center, Suite 803, Evanston, IL 60621; telephone number: 847-475-1520; fax: 847-475-6240; e-mail: abts_evanston@msn.com. The booklet is also published on the Web site: www.abts.org. 